направления необходимо понимать, что экономическое сознание и мышление занимают главенствующие позиции, это связано с основой понимания экономической жизни общества. Получение понимания происходит на основании повышения эффективности производства и реорганизации структуры, основных законов экономического развития, улучшение производственных отношений и управление системами.

По мере того, как студенты становятся экономически подготовленными, они осознают свой личный потенциал, устраняют сложные функциональные проблемы и приобретают сознательные, ответственные и творческие знания, навыки и способности. Формирование экономической компетентности студентов относится к учебной программе, которая объединяет содержание, формы, средства и методы обучения, которые обеспечивают экономическое развитие и образование для людей. Это отражается на поведении и финансовых навыках студентов.

$$
* * *
$$

1. Афанасова, Д.К. Особенности формирования профессиональной компетентности экономиста / Д.К. Афанасова // Среднее профессиональное образование. - 2008. - № 9. - С. 57-58.

2. Варакина, Е. А. К вопросу о структуре экономической компетентности руководителя образовательного учреждения / Е.А. Варакина // Вестник Костромского гос. университета им. Некрасова. - 2008. - № 3. - С. 15-20.

3. Ефремова, Н.Ф. Подходы к оцениванию компетенций в образовании. / Н.Ф. Ефремова. - Ростовна-Дону: Аркол, 2009. - 228 с.

4. Зимняя, И.А. Ключевые компетентности как результативно-целевая основа компетентностного подхода в образовании / И.А. Зимняя. - М.: Исследовательский центр проблем качества подготовки специалистов, 2007. - 235 с.

5. Иванов, Д.О. О ключевых компетенциях и компетентностном подходе в образовании / Д.О. Иванов // Школьные технологии. - 2007. - № 7. - С. 52.

6. Лебедев, О.Е. Компетентностный подход в образовании / О.Е. Лебедева // Школьные технологии. - 2004. № 5. - C. 3-12.

7. Мислицкая, А.А. Психолого-педагогический компонент профессиональной компетентности современного педагога [Электронный pecypc]. - Режим доступа: http://w.rusnauka.com/40_OINBG_2014/Pedagogica/5_183330.doc.htm. (Дата обращения: 17.02.2021.

8. Старикова, Л. Д. Формирование экономической компетентности студентов в системе профессионально-педагогического образования / Л.Д. Старикова // Теория и практика профессионального образования: педагогический поиск: сб. науч. тр. - Екатеринбург: Изд-во Рос. гос. проф. пед.ун-та, 2008. - Вып. 10. - С. 163 - 167.

9. Хуторской, А.В. Ключевые компетенции как компонент личностно-ориентированной парадигмы образования / А.В. Хуторской // Народное образование. - 2003. - № 2. - С. 58-64.

\title{
Опарина К.С. \\ Технологии систематизации информации в обучении иностранному языку студентов технического вуза
}

ФГБОУ ВО «Самарский государственный технический университет» (Россия, Самара)

doi: $10.18411 / \mathrm{lj}-06-2021-183$

\section{Аннотация}

Данная статья посвящена анализу скрайбинга и майндмэппинга как технологий, эффективных для понимания и структурирования информации, содержащейся в тексте. В практической части исследования приводится описание результатов применения рассматриваемых технологий на занятиях по иностранному языку со студентами факультета архитектуры.

Ключевые слова: технический университет, language for specific purposes, скрайбинг, майндмэппинг, продуктивные и рецептивные виды речевой деятельности. 


\section{Abstract}

This article deals with the analysis of scribing and mind mapping as technologies that are effective for understanding and structuring the information in the text. Results of applying of considered technologies foreign language classes with students of the Faculty of Architecture is given in the practical part of this research.

Keywords: technical university, language for specific purposes, scribing, mind mapping, receptive and productive language activities.

Современные образовательные стандарты требуют от выпускников технических вузов не только сформированных профессиональных знаний, умений и навыков, но и владения как минимум одним иностранным языком, что соответствует принципу обучения иностранному языку для специальных целей (Language for Specific Purposes). Однако в условиях небольшого количества учебных часов, предназначаемых для изучения дисциплины «Иностранный язык», для студентов является весьма затруднительным в полной мере освоить весь объем лексического, грамматического и страноведческого материала.

Необходимо также учитывать тот факт, что сам принцип организации занятий по иностранному языку в техническом вузе претерпел изменения. Чтение и письменный или устный перевод на русский язык текстов по специальности отходят на второй план, и все больше внимания уделяется интерактивным заданиям. Однако при этом тексты, посвященные профессиональной тематике, являются базой для говорения и письма. Поэтому студенты должны уметь осуществлять быструю обработку и компрессию содержащейся в ней информации.

Для достижения этой цели в Самарском государственном техническом университете (СамГТУ) на занятиях по иностранному языку на протяжении нескольких последних лет внедрялись технологии скрайбинга и майндмэппинга, вызывающие в последние годы вызывают большой интерес у педагогов [2, 5-8].

Термин «скрайбинг» произошел от английского глагола scribe - чертить, размечать, а термин «майндмэппинг» имеет множество вариантов перевода на русский язык: ментальная карта, интеллект-карта, когнитивная карта, карта мыслей, ассоциативная карта, карта знаний, мыслительная карта, карта структурирования.

В данной статье технология скрайбинга понимается как визуализация достаточно сложной информации простыми графическими образами. В свою очередь майндмэппинг можно определить как структурирование текста с помощью ключевых слов и понятий и взаимосвязей между ними [3]. При этом многие исследователи технологии скрайбинга подчеркивают, что создание набросков носит спонтанный характер, то есть они создаются в процессе выступления говорящего и, соответственно, используются в устной речи $[1,6]$. Кроме того, скрайбинг ориентирован на слушателя, который следит за ходом мысли докладчика или рассказчика [9].

Студентам СамГТУ был предложен иной алгоритм работы. Они получали тексты по специальности, преимущественно в качестве домашнего задания. После чтения и уточнения значения незнакомых слов учащиеся должны были сделать небольшие рисунки или наброски, передающие смысл данного текста. По тем аспектам содержания текста, которые сложно или невозможно было выразить графически, можно было выписать ключевые слова и выражения. В качестве примера можно привести текст «Тор 5 Construction Innovations», изучаемый в разделе 4 «Acoustics, Furniture and Light» учебника для будущих архитекторов и дизайнеров [4]. Студенты легко создали схематические изображения различных видов мебели и выписали лексические единицы, характеризующие встроенную и отдельно стоящую мебель и советы по ее размещению в помещении. После выполнения этой предварительной работы с текстом итоговое задание по изучению данного раздела было выполнено 
практически всеми учащимися на высоком уровне: Exercise 25. Now draw the interior yourself. Ask your partner to present your design to the audience [4, c. 76].

В заключение необходимо отметить, что интерактивные технологии работы с текстами помогают студентам не только сформировать необходимую лексическую базу, но и являются эффективными в обучении выстраиванию причинно-следственных связей, что необходимо для успешного выполнения заданий на устные и письменные монологические и диалогические высказывания.

$$
* * *
$$

1. Анохина Л. В. Применение скрайбинг-технологии в вузе // Аллея науки. 2018. Т. 6 . № 5 (21). С. 1032-1036.

2. Беляева Е. А., Фахрутдинова А. В. Инновационные технологии скрайбинга, майнд-мэппинга, вебквеста и массовых открытых онлайн-курсов в обучении иностранному языку // Иностранные языки в современном мире. Сборник материалов XII Международной научно-практической конференции. Под редакцией Д. Р. Сабировой, А. В. Фахрутдиновой. Казань: Казанский (Приволжский) федеральный университет. 2019. С. 26-31.

3. Вахрамеева Д. Д., Тучкова А. С. Технология майндмэппинга // Тенденции развития науки и образования. 2019. № 55-2. С. 8-10.

4. Градалева Е. А., Полухина М. О., Юрина М. В. Contemporary Architecture \& Design: Developing Motivation in English Language Study Using Traditional Methods and Information Technology. Самара: Самарский государственный технический университет, 2019. 163 с.

5. Калашникова А. В., Ковальчук Т. В. Скрайбинг как инструмент визуализации мышления на уроках английского языка // Воспитание и обучение: теория, методика и практика. Сборник материалов XI Международной научно-практической конференции. Редколлегия: О.Н. Широков [и др.]. Чебоксары: Общество с ограниченной ответственностью «Центр научного сотрудничества «Интерактив плюс». 2017. С. 416-418.

6. Киселева А. В. Современные образовательные технологии: скрайбинг // Сборники конференций НИЦ Социосфера. 2016. № 9. Прага: Vedecko vydavatelske centrum Sociosfera-CZ s.r.o. C. 124-126.

7. Куманькина И. П. Технология скрайбинга в изучении английского языка // Актуальные проблемы германистики и методики преподавания иностранных языков. Сборник научных трудов по материалам VIII Международной научно-практической конференции. Саранск: Мордовский государственный педагогический институт имени М.Е. Евсевьева. 2018. С. 136-141.

8. Овчинникова Е. С., Овчинникова М. С. Скрайбинг, скетчноутинг и майндмэппинг как средства изучения иностранных языков // Обучение иностранному языку: современность и перспективы. сборник научных статей региональной научно-методической конференции, посвященной 55летию Юго-Западного государственного университета и кафедры ин. языков. Курск: ЮгоЗападный государственный университет. 2019. С. 320-328.

9. Сакулина Ю.В. Возможности использования скрайбинг-технологии для повышения уровня усвоения теоретического материала // Проблемы современного образования. 2020. № 4. С. 172 180.

\section{Помян С.B.}

Мониторинг успеваемости студентов и управление учебным процессом в вузе

Приднестровский государственный университет им. Т.Г. Шевченко (Молдова, Тирасполь)

doi: $10.18411 / \mathrm{lj}-06-2021-184$

\section{Аннотация}

В статье рассмотрена проблема мониторинга успеваемости студентов и управление учебным процессом в вузе с помощью прогноза результатов успеваемости студентов вуза. Для формирования прогноза использован математический аппарат марковских процессов. В ходе исследования разработана методика прогнозирования, апробированная на примере инженерно-технического института. В результате установлено, что методика наилучшим образом применима к категории отчисляемых 